\title{
Service encounter microblog word of mouth and its impact on firm reputation
}

\begin{abstract}
Purpose - It has now become a normal part of the consumption journey for consumers to share their positive and negative service encounters with firms on microblogs such as Twitter. This study examines the impact of SEMWOM (service encounter microblog word of mouth) on an important actor in the microblog domain-receivers of positive and negative valence SEMWOM. As such, this study aims to understand the comparative effects of positive and negative valence SEMWOM on perceptions of firms' reputation.

Design/methodology/approach - An experiment exposed 372 Twitter users to positive and negative valence SEMWOM about airlines. To determine whether changes in perception of firm reputation occurred on exposure to both positive and negative valence SEMWOM, participants' perceptions of a range of U.S. airlines were measured before and after exposure to the SEMWOM. To confirm the factors that influence the perception of reputation on such exposure, six structural equation models (SEMs) were crated to determine the comparative effects of positive and negative valence SEMWOM on three eWOM media: video, photo, and text.
\end{abstract}

Findings - Both positive and negative valence SEMWOM affect receivers' perceptions of airlines' reputations on exposure. Furthermore, the factors that influence perceptions of reputation on exposure to SEMWOM vary depending on valence and type of media contained in a Tweet.

Originality/value - Although consumers now routinely share their positive and negative service encounters with brands on microblogs, scant research has examined receivers of positive and negative valence SEMWOM, important actors in the microblog domain. This study addresses this research gap by empirically investigating the impact of both positive and negative valence SEMWOM on receivers' perceptions of firm reputation on exposure to it.

Keywords Service encounter, social media, airline industry, e-wom 


\section{Paper type Research paper}




\section{Introduction}

The advent of customers sharing their service encounters with firms through social media has received a tremendous amount of media coverage over the last few years. From a video of Dr. David Dao being forcibly removed from a United Airlines flight for refusing to give up his seat (Bowerman and Aulbach, 2017), to a family being escorted off of a Southwest airlines flight due to an unruly child (Fearnow, 2018), consumers increasingly share their positive and negative service encounters with firms on social network sites such as Twitter (Abney et al., 2017). They do so via mobile-empowered devices and a range of user-generated content (UGC) via text, photos and videos. Firms therefore have a tremendous opportunity to not only engage back with those that mention them, but they must also be wary of negative mentions specifically as they could be potentially damaging to their reputations (Berthon et al., 2012; De Maeyer, 2012; Cheng and Loi, 2014; Grégoire et al., 2015; Rauschnabel et al., 2016; Stevens et al., 2018). In addition, and perhaps just as important, positive mentions have the propensity to affect brand outcomes such as increasing sales (Wang et al., 2015; Marchand et al., 2017).

A stark reality, however, is the limited understanding of the impact that exposure to service encounters in microblogs such as Twitter has on a very important actor within the microblog domain - receivers of positive and negative valence SEMWOM (service encounter microblog word of mouth). Through SEMWOM, receivers of Tweets are exposed to information about firms through the Twitter users that they follow. Whether complaining about the annual release of Starbucks' pumpkin spice latte in the hot summer months (Kooser, 2018), or bank account failures when debit cards do not work properly (Rumney, 2018), consumers are increasingly telling others about their service encounters on platforms such as Twitter. As a result, firms have transformed their customer service operations with Twitter response teams. For example, with approximately 2,500-2,600 Twitter mentions every day, JetBlue, a U.S.-based 
airline, has a specialized Twitter social media team comprised of customer service agents, corporate communications and marketing to not only engage with customers in the environment in which they are choosing to contact them, but also to manage the volume of tweets they receive each day (Kolowich, 2014).

Such investment and transformation, however, beg several questions. For example, what is really known about the impact that positive and negative SEMWOM has on the receivers of this information? Does it influence perceptions of the firms' reputations that are portrayed? Is there cause for concern when negative service encounters are shared? Perhaps as important, are positive mentions about service encounters influential? What factors of a shared service encounter in microblogs are particularly salient to a change in perception of a firm's reputation if one does occur? Exploring this question is important, as a firm's reputation has been linked to sound financial performance and sustained competitive advantage (Walker, 2010).

Understanding the influence of SEMWOM on firm reputation is therefore of paramount importance, yet there is a dearth of research that examines service encounters shared in microblogs specifically, and their impact on perceptions of firm reputation. We do so in this study with the operationalization of quantitative research in the form of an online, within-subject experiment in which 372 Twitter users were exposed to positive and negative valence SEMWOM about airlines. To determine whether a change in perception of firm reputation occurred upon exposure to both positive and negative valence SEMWOM, we measured participants' perceptions of a range of U.S. airlines before and after exposure to tweets. To confirm the factors that influence a change in perception of reputation on such exposure, we created six structural equation models (SEMs) to determine the comparative effects of positive and negative valence SEMWOM among three eWOM media: video, photo, and text. 


\section{Literature review}

Importance of a firm's reputation

A firm's reputation is a stakeholder's overall evaluation of a firm that is based on experiences, or any other form of communication and interaction (direct or indirect), that provides information about the firm's actions and/or a comparison with the actions of other leading rivals (Gotsi and Wilson, 2001). For the firm, a positive and strong reputation helps it to market services (Lewis and Booms, 1983), provide an optimal marketplace position (Walker, 2010), mitigate threats, and exploit opportunities (Argenti and Druckenmiller, 2004). In addition, a strong, positive reputation can be called upon as a strategic resource to create a competitive advantage (Abratt and Kleyn, 2012), and has also been linked to sound financial performance, customer loyalty, and customer commitment and trust (Walker, 2010).

For consumers, a firm's reputation can help them make decisions about firms' products and services, especially when confronted with a range of products and services that are similar in price (Greyser, 1999). It does so by providing a frame of reference, thereby reducing the complexity of information processing, and providing the ability to apply heuristics when consumers are making decisions about products and services (Poiesz, 1989). Given its strategic importance for the firm, and the value it provides to consumers, a firm's reputation must therefore be consistently monitored and protected. Doing so today presents unique challenges for firms however as consumers share their positive and negative experiences of them in the form of electronic word of mouth (eWOM) and UGC, increasing the scale and reach that individuals have to potentially influence reputation.

eWOM and $U G C$

In platforms such as Twitter, service encounters are shared through word of mouth (WOM) in the form of UGC. WOM is a powerful source of information for consumers and has long been 
acknowledged as more influential than firm-controlled communications (Allsop et al., 2007) and as having the potential to affect firm reputations (Allsop et al., 2007; Sweeney et al., 2012).

Generally associated with one-to-one, non-commercial information that consumers share with others about their experiences with firms (Daugherty and Hoffman, 2014), the construct has evolved to include that shared electronically (eWOM) and on various platforms (Marchand et al., 2017; Pasternak et al., 2017). UGC shared on social media sites such as Twitter concerns content that has been created outside of professional routines and practices by users of a site or community (Kaplan and Haenlein, 2010). In the service encounter context, UGC in the form of eWOM shared on microblogs can present unique challenges to firms.

SEMWOM and reputation

One of the key aspects that firms must contend with in the digital environment today is the risk posed to firms' reputations by social network site users. Research demonstrates that eWOM is a powerful source of information that can potentially be debilitating to firms who are faced with managing their reputations in this domain (Breazeale, 2009; Kaplan and Haenlein, 2010; Fournier and Avery, 2011; Siano et al., 2011; Berthon et al., 2012; Cheng and Loi, 2014; Pasternak et al., 2017). This is due to the fast-moving nature of social media and the inherent potential to reach many as WOM in this realm (eWOM), has been transformed with regard to reach and scale (Breazeale, 2009). As such, managing a firm's reputation has become a significant challenge for firms in such environments as consumers share the good, bad and ugly of their experiences with firms as a normal part of their consumption journey. It is thus important for firms to understand the potential impact that various forms of WOM can have on their reputations and take actions to manage it. This continues to be a challenge, however, as a limited amount of research focuses on the type of environment and the context in which eWOM is 
shared. For example, recent literature has begun to acknowledge the various social media platforms available and the impact that eWOM can have within these platforms (see Marchand et al., 2017; Pasternak et al., 2017), but there is still a need to also consider the context and the environment in which eWOM is shared. We thus delineate SEMWOM from other types of eWOM.

With regard to the context, service encounters are primarily social interactions between the service provider and the service receiver (Henkel et al., 2017). Hence, the service component of these encounters is the major element of the offering - regardless of whether the core element of the offering is a material good or a service (Solomon et al., 1985). Accordingly, during a service encounter, the service provider's behavior is crucial as it can influence consumers' evaluations of firms' reputations (Sengupta et al., 2015). In today's environment in which consumers are sharing their positive and negative service encounters with brands as they are actively consuming them, a unique context is presented when compared to other forms of eWOM such as review sites such as TripAdvisor or Yelp. This is due to the nature of the environment in which service encounters are shared within microblogs. Microblogs are social media sites that enable users to send and read very short messages with a restriction on the number of characters that can be used in the message. Microblogging applications not only include social media sites such as Twitter in the United States and Weibo in China, but also include social media applications that have microblogging features called "status updates" (e.g. status updates on Facebook and LinkedIn) (Stieglitz and Dang-Xuan, 2013). The most popular microblogging site is Twitter, which allows users to send tweets limited to 280 characters, also referred to as micro-sharing, micro-updating, "twittering," and "tweeting" (Jansen et al., 2009; 
Hennig-Thurau et al., 2015). Consumers, celebrities, and political figures increasingly use Twitter to share stories, thoughts, and perceptions.

In addition, microblogs have been identified as a unique environment in which information is pushed to consumers, rather than other forms of eWOM such as review sites in which it is pulled (Marchand et al., 2017). It is therefore inherently unique due to the limitation on the amount of information one can share and the potential to spread information very quickly (Hennig-Thurau et al., 2015). Further, it has been highlighted within the literature that microblogs such as Twitter present a unique environment in which users can immediately share their positive and negative experiences with brands as an integral part of their consumption journey (Hennig-Thurau et al., 2015, Marchand et al., 2017). More data are required however to understand the impact of various types of WOM and in the context in which they are shared. Hence, we focus our study on service encounter WOM shared via microblogging, or SEMWOM in this study, and commence with the following hypotheses:

H1. Exposure to positive valence SEMWOM will positively affect firm reputation $H 2$. Exposure to negative valence SEMWOM will negatively affect firm reputation Factors that influence eWOM effectiveness Although several assertions have been made with regard to the potential impact that eWOM about brands can have on a firm's reputation, there is a dearth of research on the SEMWOM factors that influence a change in perception of reputation from the receiver's perspective. There has however been research conducted to explore the factors of eWOM that are particularly important to other brand outcomes, and this literature is explored next.

Information usefulness. Information usefulness, or argument quality/strength, has been shown to influence the attitudes of receivers of eWOM (Berger and Milkman, 2012; Cheng and Loi, 2014; Teng et al., 2014b). Hence, as Twitter users are exposed to a range of content in a 
fast-moving environment, it would be expected that the usefulness of SEMWOM could influence a receiver's evaluation of reputation upon exposure. Thus, we include a variable that represents this attribute and test the following hypothesis:

H3. The extent to which receivers find SEMWOM to be useful will influence their evaluation of a firm's reputation

eWOM credibility. The credibility of information (Cheung et al., 2009; Yusuf et al., 2018) also plays an important role in eWOM effectiveness. eWOM credibility is how truthful or believable the eWOM recipient finds the eWOM to be (Cheung et al., 2009) and is seen to be more credible than organizational messages (Kumar et al., 2017; Pasternak et al., 2017) as they have passed through a filter of 'people like me' (Allsop et al., 2007). One could posit that 'SEMWOM message credibility' is of importance within a microblogging environment (e.g. if the receiver of SEMWOM finds the message to be believable and trustworthy, a change in a reputation could occur depending on the argument being made). Thus, we include a variable representing SEMWOM credibility in the model and hypothesize the following:

H4. The extent to which receivers find SEMWOM to be credible will influence their evaluation of a firm's reputation

Emotions. The emotional aspect of eWOM is an area that has limited empirical research, yet has been acknowledged to require further exploration (Kim and Gupta, 2012; Stieglitz and Dang-Xuan, 2013; Standing et al., 2016). It is thus a burgeoning area of research with a few notable studies. Focusing on Twitter specifically, Stieglitz and Dang-Xuan (2013) found that emotionally charged Twitter messages were retweeted more often and more quickly compared to neutral ones. In addition, Standing et al. (2016) undertook a case study of a Swedish firm and its communication campaigns for a two-year period. The researchers monitored comments after 
three campaigns on Kickstarter, Twitter and Facebook and their findings suggest that users expressing emotion were faster at spreading eWOM to their community. As Twitter users share their positive and negative service encounters with firms as they carry out their routine transactions, it is plausible that the emotions felt by the receivers of these shared service encounters would play a role in receivers' evaluation of a firm's reputation. We include variables representing these felt emotions and test the following hypothesis:

H5. The emotions receivers feel upon exposure to SEMWOM will influence their evaluation of a firm's reputation

Cognitive information processing. The way in which eWOM receivers process information has been seen as an enabler of effective eWOM through attitude change (Cheung and Thadani, 2012; Teng et al., 2014a). The elaboration likelihood model was a model created by Petty and Cacioppo (1980) and posits that the attitude formation process is dependent upon the extent to which message receivers elaborate, or think about, issue-relevant arguments within a persuasive communication. When receivers of a persuasive communication possess a relatively high motivation to process information, they employ the central route. The central route requires more elaboration, or thinking and consideration of issue-relevant arguments. As Chu and Kamal (2008, p. 28) stated, "in this condition, people combine and integrate issue-relevant information into an overall evaluation reaction." The peripheral route requires less cognitive processing and includes such cues as source characteristics or the level of expertise the information source is perceived to have.

In a fast-moving microblog environment such as Twitter, it is difficult to know how receivers of messages process SEMWOM and it is therefore asserted here that a good model should include both a central route (giving an indication of a motivation to process more 
information) and a peripheral route (giving an indication of less thinking and more heuristics involved with regard to information processing) variables. The model created for this study includes both with the expectation that doing so will increase the explanatory power of any outcomes. In addition, we test the following hypothesis:

H6. Upon exposure to SEMWOM, the likelihood of processing further issue-relevant information will influence receivers' evaluation of a firm's reputation

Source style. Source style is a relatively new feature of eWOM that has been highlighted as affecting eWOM effectiveness and has had very little research to date (Lin et al., 2012; Teng et al., 2014b; Wang et al., 2015). It has been noted that online reviews within social media can be the combination of text and visual cues and that visual information exerts a significant impact on users' online information acceptance (Teng et al., 2014b). In relation to eWOM effectiveness, recent studies have come to the fore and demonstrated the impact of source style. One study demonstrated that visual information such as photographs can be more influential than text alone (Lin et al., 2012), and another demonstrated that benefit-centric reviews have more impact than attribute-centric reviews (Wang et al., 2015). In the microblog Twitter, one can be exposed to a tweet with text only, a tweet with a photograph and a tweet with a video. There is however, limited research regarding the impact that source style has within microblogs such as Twitter. Therefore, we hypothesize:

H7. The factors that influence receivers' evaluation of a firm's reputation upon exposure to SEMWOM with visual information will have more of an impact on reputation than SEMWOM with text only

\section{Conceptual model}

In the context of positive and negative valence SEMWOM, and any influence it has on receivers' evaluation of reputation after exposure, eleven different dependent variables were created for the 
model based on the categories identified in the literature: SEMWOM Message Usefulness; SEMWOM Message Credibility; SEMWOM Issue Involvement and eight SEMWOM Emotions. With regard to emotions, and as a result of pilot tests, a slightly modified version of Plutchik's (2001) eight basic emotions were used. The emotions used included: joy, sadness, anger, approval, disgust, fear, surprise and not surprised. The impact of 'source style' was examined with the inclusion of the various types of tweets available at the time of the study -tweets with text only, tweets with a video and tweets with photographs. The model includes both peripheral and central route persuasion variables. A depiction of the conceptual model is provided in Figure 1.

\section{[INSERT FIGURE 1 HERE]}

\section{Methodology \\ Methodology selection}

We undertook quantitative research in the form of an online quasi-experiment with a questionnaire through Qualtrics. Although recent studies have focused on examining eWOM in microblogs and its effectiveness through aggregate data capture (Stieglitz and Dang-Xuan, 2013; Hennig-Thurau et al., 2015; Marchand et al., 2017), research on receivers of SEMWOM and whether an individual instance of SEMWOM can influence their perceptions of a firm's reputation is scarce. In addition, only limited research has examined receivers in particular and the factors related to SEMWOM that influence a receiver's evaluation of a firm's reputation after exposure. As such, we operationalized a within-subject, pre-test/post-test experiment design because of the nature of the microblog environment and the way receivers are exposed to SEMWOM.

As the main overarching objective of this study was to explore the microblog environment and the factors that influence a receiver's evaluation of firm's reputation upon exposure to 
SEMWOM, it was determined that a focus on the airline industry would be pertinent. It has become standard industry practice for the airline industry to engage with customers via social media, and specifically through Twitter in the United States (Wolfe, 2018). Thus, with regard to the high percentage of Twitter users located in North America, the country chosen for this research was the United States.

Research has demonstrated the varying effects of environments (Marchand et al., 2017) on eWOM's effectiveness and the uniqueness of microblogs in the broader eWOM context (Hennig-Thurau et al., 2015). We thus designed the experiment not only to simulate what would happen in an actual Twitter environment, but also to determine receivers' perceptions of a firm's reputation both before and after exposure to SEMWOM. This form of experiment enabled us to glean useful insights into receivers of SEMWOM and its impact on reputation, compared to an aggregate data capture in which insights may have been more limited.

Both positive and negative valence eWOM have been demonstrated to play a key role in eWOM effectiveness. Some studies have demonstrated that negative valence eWOM can have a stronger impact on eWOM outcomes than positive eWOM (Teng et al., 2014b; Hennig-Thurau et al., 2015), while others have demonstrated positive valence eWOM to be more effective (Wang et al., 2015). As such, both positive and negative valence SEMWOM were incorporated in this study to explore the role of valence in the Twitter environment.

With regard to the population of interest, the Pew Research Center (2018) indicates that the highest percentages of Twitter users (40\%) are between the ages of 18 and 29 years, followed by $30-49$ years $(27 \%)$. In addition, the United States is one of the most prominent locations of Twitter users, with 57\% having some college education. Thus, we identified college-educated Twitter users between the ages of 18 and 49 years, who resided in the United States, as the 
population of interest. We chose the access panel Prolific Academic as the sampling frame. Use of the panel facilitated flexible pre-screening and enabled us to operationalize a study comprised of 372 male (212) and female (160) college-educated Twitter users between the ages of 18-24 years $(62 \%), 25-34$ years $(31 \%), 35-44$ years $(6 \%)$ and $45-54$ years $(1 \%)$.

Operationalization of the experiment

Step 1: Initial evaluation of the airlines. The experiment was comprised of three steps to meet the objectives of the study. First, we asked participants to provide an evaluation of eight U.S.-based airlines' reputations by means of the Net Promoter Score (NPS) question (we provide a detailed explanation of the use of this question as a proxy for firm reputation in the next section). Participants rated how likely they would be to recommend these airlines to a friend or colleague. We used the ratings firm Skytrax to determine which airlines to include in the experiment. As we wanted to obtain a composite representation of study participants' overall evaluation of the airlines included in steps 2 and 3, we decided that airlines rated as three stars, or average, would be optimal to curtail the variable effects of familiarity and involvement with the airlines. Skytrax (2018) describes 3-star airlines as "airlines delivering a fair quality performance equating to an industry 'average' of acceptable product and service standards." The rationale for this step was not only to capture participants' evaluations of airlines rated as average, but also to minimize the risk of recalling their answers later after exposure to the SEMWOM and being asked the NPS question again. Airlines included in the experiment were Delta, American, United, Southwest, Hawaiian and US Airways.

Step 2: Exposure to SEMWOM. Next, all participants were asked to imagine that they were exposed to the tweets shown in the experiment as they appear in their Twitter timeline. Experiment participants were then exposed to six actual positive and negative valence 
SEMWOM (examples can be seen in the Appendix, Figures A1-A3) for six of the airlines included in step 1, inclusive of the different types of tweets (i.e. tweet with text, tweet with photograph, and tweet with video). Twitter's Advanced Search feature was used to find tweets that were about service encounters with airlines, non-commercial in nature, positive and negative in valence, and in the United States. To confirm the valence of tweets, we searched for tweets that had smiling or frowning face emoticons and emotional words that could be considered positive or negative in valence (Kim and Gupta, 2012). Two pilot studies enabled us to further confirm the valence of the tweets, to make any necessary changes to the experimental design, and determine the average amount of time for participants to take part in the experiment. We reduced carry-over effects, or order effects, by randomizing the order of presentation of the types of tweets (Field and Hole, 2002).

Step 3: Questionnaire. In the third step, the participants answered a series of questions about the tweets, including a follow-up NPS question. We employed a range of scales to assess the factors that influenced receivers' evaluations of the airlines' reputations after exposure to the SEMWOM. In addition, we randomized the order of questions in our questionnaire consistent with recommendations of Gehlbach and Barge (2012) to avoid anchoring issues related to individual constructs. The Likert scale used for these ran from 1 to 5 .

\section{Measures}

We measured participants' perceptions of the airlines' reputations at two points: before exposure to the SEMWOM and after through the use of the NPS question. Although researchers have questioned the validity of the NPS to measure company profitability and brand loyalty (Grisaffe, 2007; Keiningham et al., 2007), we chose the NPS to represent firm reputation for three reasons. First, we used the NPS question to represent reputation to obtain a snapshot inference of 
reputation both before and after participants were exposed to the tweets due to its extensive use in the practitioner domain. Developed by the consulting firm Bain \& Company, Robert Reichheld and Sametrix, the NPS question was designed as a simple metric to help firms understand their propensity for future growth and to manage relationships with their customers (Bain, 2020). Since its inception in 2003, it has not only been adopted by a range of firms, including Delta and Southwest Airlines (Bain, 2020), but is also regularly used as an industry benchmark for firms' reputations. For example, firms with high NPS scores have been referenced as world-class companies (Hyken, 2018) and those which consumers consider the 'best of the best' (Griffith, 2018). Sametrix, in describing the use of the question, instructs practitioners to "use your NPS as the key measure of your customers' overall perception of your brand" by using a 0-10 scale to ask how likely is it that you recommend [brand] to a friend or colleague" (Satmetrix, 2019).

Second, assessing reputation requires a degree of cognitive effort and evaluation by receivers, and microblogs such as Twitter are unique environments in which users are exposed to information at an "unprecedented" speed (Hennig-Thurau et al., 2015). Having one question enabled us to more closely simulate what would happen in real time in the Twitter environment by keeping the experiment as brief as possible while also measuring any changes to participants' perceptions of firms' reputations. The NPS question suited these requirements, as the NPS scale consists of 10 points. We examined SEMWOM's impact on receivers' perceptions of reputation by assessing whether there was any movement in the scale before and after exposure to the tweets. We did so by employing paired-samples t-tests. Third, other disciplines recognize the utility of one question in terms of brevity and simplicity and of making fewer demands on respondents; it is also reliable and valid (Bowling, 2005). 
In addition to participants' evaluations of the airlines' reputations, we measured other constructs that influence eWOM effectiveness. To keep the experiment as brief as possible, we employed a combination of single-item and modified multi-item scales to explore the factors that influence receivers' evaluation of the airlines after exposure to the SEMWOM. Table A.1 in the Appendix provides the constructs measured and the scale and non-scale items.

\section{Results}

Paired-samples t-test results

To understand which variables influence receivers' evaluation of firms' reputation upon exposure to SEMWOM, it was first necessary to understand whether a change in the perception of the airline's reputations had actually occurred and, if so, to what extent. We selected the t-test as the measurement instrument because the same participants were asked the same NPS question on two occasions, before and after exposure to the tweets. Employing a paired-samples t-test enabled us not only to determine whether there was an actual change in perception of reputation, but also to understand the extent of the change. It was also an applicable method to use because the data was normally distributed, independent, and interval based (Tabachnick and Fidell, 2013).

As Table I shows, the significance value of the t-tests was $.000(p<.01)$, indicating a significant difference between the NPS score given by experiment participants both before and after exposure to the positive and negative valence SEMWOM (supporting H1, H2). Further, Table I shows that the initial and final NPS scores are correlated. This finding confirms the observation that firm reputation is at least somewhat robust to positive or negative SEMWOM. A pairwise test of the differences shows that the change in NPS score within each study participant is statistically significant. In addition, the signs of these changes are in the anticipated direction. Finally, the results show that $\mathrm{H} 7$ was not supported, as the impact of SEMWOM with visual 
information on reputation was not consistently greater than SEMWOM without it. Next, we move to the structural equation models.

\section{[INSERT TABLE I HERE]}

\section{PLS-SEM results}

Six PLS-SEM models were created to determine the factors that influenced receivers' evaluation of the airlines' reputations after exposure to the SEMWOM. Eleven different independent variables, demonstrated in Table A.1 in the Appendix, were tested in the models based on the literature review on variables that influence eWOM effectiveness.

To assess the validity of the measurement models, the methods detailed by Wong (2013) and Hair et al. (2016) were employed. Discriminant validity was established when the factor loading coefficients for the items that constituted each latent variable were greater than their cross-loadings on alternative latent variables. The cross loadings for the models were assessed and all six models fit the criteria. Convergent validity was established as the average variance explained (AVE) by the multiple indicators of each latent variable was greater than 0.5 . Internal consistency reliability was established, as all of the composite reliability coefficients for the latent variables were $>0.6$. These are demonstrated in Tables A.2 and A. 3 in the Appendix.

We estimated the statistical significance of each path coefficient $(\beta)$ through bootstrapping. We randomly sampled the raw data 5,000 times and computed the mean of each $\beta$ coefficient. To confirm the validity of our models, we use Cronbach's alphas and the composite reliability scores. These are demonstrated in Tables A.2 and A.3 in the Appendix.

Tables II and III display the significant predictors and hypotheses results of the factors that influence receivers' evaluation of reputation after exposure to SEMWOM of the six PLSSEM structural models based on the data for the six tweets. To assess the comparative impact of 
SEMWOM, we use the final NPS as our dependent variable and include the initial NPS score as an explanatory variable. If firm reputation as proxy by NPS is perfectly robust to this type of exposure, then we would find that all of the variation in the final NPS would be explained by the initial NPS. If firm reputation is perfectly fragile, then the initial NPS would have no impact in these models.

In the positive models, the initial NPS score is highly statistically significant in each model. Correspondingly, the relative size of its coefficient is large compared to the other variables. To further decompose the robustness of firm reputations, we compare this new PLSSEM model to an OLS of the final NPS using only the initial NPS and intercept as variables. The coefficient of determination is shown in Panel B of Table II. By comparing the coefficients of determination, we find that the initial NPS explains roughly $14.7 \%, 12.4 \%$, and $34.1 \%$ of the variation in the final NPS for the video, photo, and text information models, respectively. The other variables in our model explain an additional $25.2 \%-45.0 \%$ of the variation in the final NPS. A comparison of the SEMWOM constructs shows that they play a significant role. SEMWOM Message Usefulness and SEMWOM Issue Involvement were significant predictors in all three positive valence models (supporting H3, H6) while SEMWOM Message Credibility (supporting H4) was a significant predictor in two of the models (the photo and text only tweets). Emotions played a more limited role in predicting the firm's reputation after exposure to the positive valence SEMWOM with joy statistically significant across each model and approval statistically significant in the video model only (supporting H5). Finally, the effect size $\left(\mathrm{R}^{2}\right)$ indicated the proportion of the variance explained in the dependent variable by the predictor variables with the video at 0.520 , the photo at 0.574 and the text only at 0.593 .

\section{[INSERT TABLE II HERE]}


Next, we present the results of the negative valence PLS-SEM models. As indicated previously, the initial NPS plays a statistically meaningful role for each type of tweet. To further decompose the robustness of firm reputations, we compare this new PLS-SEM model to an OLS of the final NPS using only the initial NPS and intercept as variables. The coefficient of determination is shown in Panel B of Table III. By comparing the coefficients of determination, we find that the initial NPS explains roughly $15.2 \%, 33.8 \%$, and $17.5 \%$ of the variation in the final NPS for the video, photo, and text information, respectively. The other variables in our model explain an additional $14.7 \%-29.5 \%$ of the variation in the final NPS. Inconsistent with findings for the positive valence results, SEMWOM Message Usefulness, SEMWOM Message Credibility and SEMWOM Issue Involvement (supporting H3, H4, and H6) are significant in one model only, the video, photo and text only tweets respectively. Again, inconsistent with the positive valence results, SEMWOM Emotions (H5) played a more important role in predicting the evaluation of a firm's reputation after exposure to the negative tweets. The emotions approval and disgust were significant in the models with visual information (the video and photo), with anger significant in the model with the most visual information (the video). The emotions joy and surprise were significant in the model with no visual information (the text only tweet). The effect size $\left(\mathrm{R}^{2}\right)$ indicated the proportion of the variance explained in the dependent variable by the predictor variables with the video at 0.447 , the photo at 0.485 and the text only at 0.366 .

In each statistically significant case, the sign of the coefficient is in the expected direction which confirms the findings in previous literature; however, we note that the interactions between type of exposure (source style) and SEMWOM constructs have materially different effects.

\section{[INSERT TABLE III HERE]}




\section{Discussion}

Today's social media environment is one that is fraught with both risks and opportunities for firms and their reputations. It is one in which people share their positive and negative service encounters with firms as they carry out their normal, everyday transactions. As such, there has been a growing reliance on social listening activities to help brand managers in their efforts to both protect and enhance their reputations. Although this is the case, there has been a dearth of research to understand the robustness of firms' reputations in specific social media environments and in various contexts. In this study, we explored the impact SEMWOM could have on a firm's reputation when receivers are exposed to positive and negative valence SEMWOM about airlines. In addition, we explored the factors that influence receivers' perceptions of reputation upon exposure to positive and negative valence SEMWOM.

\section{Impact of positive and negative valence SEMWOM on reputation}

A firm's reputation is a key strategic asset that is formed when stakeholders are directly or indirectly exposed to information about the firm, or have direct or indirect experiences of a firm (Gotsi and Wilson, 2001). Although numerous assertions have been made in the literature with regard to the power of eWOM to influence firm outcomes (e.g. Berthon et al., 2012; De Maeyer, 2012; Cheng and Loi, 2014; Grégoire et al., 2015), there is a dearth of research on eWOM in specific contexts and environments and its ability to influence perceptions of firm reputation. The results from this study suggest that both positive and negative valence SEMWOM have an impact on receivers' perceptions of firm reputation while source style (type of Tweet: video, photo or text only) does not. Whether receivers were presented with a photo of a smiling flight attendant serving a beverage during a Hawaiian Airlines flight, or text about a lack of apology from American Airlines (see Appendix Figures A.1 and A.3), exposure to the service encounter resulted in an increase in perception of reputation upon exposure to positive SEMWOM, and a 
decrease in perception upon exposure to negative SEMWOM. The findings in this study therefore add to the extant literature on reputation with regard to the specific context (service encounters) shared in specific environments (microblogs) with a particular source style (type of SEMWOM).

Role of valence and route to persuasion in positive valence models Valence (whether the SEMWOM was positive or negative in nature) and routes to persuasion (central and peripheral) were examined in this study as both have been acknowledged in the literature as affecting eWOM outcomes. With regard to the positive valence SEMWOM, the three models demonstrated emphasis on both peripheral $(P)$ and central $(C)$ route persuasion variables with SEMWOM Issue Involvement (C), SEMWOM Message Usefulness (P), SEMWOM Credibility $(P)$, and the emotions $(P)$ joy and approval as significant predictors. These findings are consistent with the literature and suggest that participants' need to process issue-relevant information, the usefulness of the information conveyed in the SEMWOM, and whether or not they found the SEMWOM to be believable and trustworthy all influence their evaluation of the firm's reputation after exposure to the positive valence SEMWOM.

With regard to the negative valence SEMWOM, peripheral route to persuasion variables dominated in the form of emotions. This outcome could be explained by the nature of the industry, the nature of the significant emotions and the influence of source style, or type of tweet. Research has demonstrated that in some circumstances, negative WOM occurs more frequently than positive WOM (Richins, 1984). The airline industry epitomizes this assertion as it is one in which it has become common practice for customers to share their complaints on social media (Wolfe, 2018). In addition, the airline industry has one of the lowest customer satisfaction scores of all industries in the United States (Morgan, 2018). The negative information shared via 
SEMWOM in this study may therefore have been more expected and accepted than the positive SEMWOM. As such, the need to process more information, assess credibility, and information usefulness were potentially not as important as emotional reactions when evaluating airlines' reputations after exposure to the negative valence SEMWOM. The results from this study therefore add to the extant literature on the role of valence of SEMWOM and the routes to persuasion taken by receivers of it.

Role of emotions in the positive and negative valence models

The emotion joy dominated positive valence models. Emotions were examined in this study as a result of acknowledgments in the literature that further research is required on eWOM (Stieglitz and Dang-Xuan, 2013; Standing et al., 2016) and their importance in the practitioner domain when conducting social listening. With regard to the positive valence models, the emotion Joy was significant in all instances. This finding is consistent with research in the advertising discipline and adds additional context to the microblog environment. For example, upon exposure to advertisements with emotion-evoking stimuli, consumers are said to form attitudes that are aligned with the nature of emotion linked to the firm in an advertisement (Hasford et al., 2015). A form of emotional contagion takes place and the feeling conveyed in the stimulus and the feeling felt by the person exposed to it converge (Hatfield et al., 1993). As the emotion Joy was significant in all three positive valence models, and the reputation of the firm increased after exposure to all three positive valence SEMWOM instances, the powerful effect of the emotion joy has been demonstrated in this study and adds to the extant literature on emotions in the eWOM context.

Several emotions were predominant in the negative valence models. With regard to the significant emotions in the negative models, the high arousal emotions disgust and anger were 
significant predictors in models with visual information (the video and photo), with low arousal emotions joy and not surprised significant in the model without visual information (the text only tweet). Research demonstrates that emotions generate various levels of psychological arousal or activation. Anger and anxiety are associated with states of heightened arousal or activation, while contentment and sadness are associated with low arousal or deactivation (Berger and Milkman, 2012). Further, disgust has been associated with avoidance reactions (Morales et al., 2012) and visceral repulsion (Shimp and Stuart, 2004), with the emotion eliciting an immediate impulse to distance oneself.

As such, the findings in this study suggest that the complex visual cues offered by the SEMWOM with video and a photo engendered a state of repulsion and a reactive state on the route to persuasion and evaluation of the airlines' reputations, versus information processing, message usefulness or credibility in the positive models. The SEMWOM with text only however only had the low arousal emotions of joy and not surprised as significant predictors. This again could be explained by the nature of the industry portrayed in the SEMWOM (i.e. what was portrayed in the SEMWOM was expected and accepted and these emotions predicted the evaluation of reputation upon exposure). These findings again add to the extant literature in the context of service encounters shared in microblogs and research on emotions in the eWOM context.

Cognitive information processing, credibility, and message usefulness are more predominant in the positive context. An important finding of the study was that SEMWOM Issue Involvement (cognitive information processing), SEMWOM Message Usefulness and SEMWOM Credibility were more predominant predictors of reputation after exposure to SEMWOM in the positive valence models than the negative valence models. These constructs were explored in this 
study as the literature espoused their influence on eWOM outcomes (i.e. the motivation to process issue-relevant information) (Chu and Kamal, 2008), the usefulness of eWOM (Berger and Milkman, 2012) and whether or eWOM is believable or not (Cheung et al., 2009) influence eWOM outcomes.

In this study, the findings again suggest that the nature of the industry portrayed could explain these outcomes. Exposure to positive service encounters could have been a catalyst to a positive disconfirmation of expectation. A positive disconfirmation of expectation occurs when firm performance is better than expected (Cadotte et al., 1987). Prior expectations are formed based on attitudes and beliefs about the brand (Oliver, 1980; Cadotte et al., 1987), personal experience, the marketing mix (Bitner, 1990) and expected norms developed as a result of experience with other brands (Cadotte et al., 1987). As such, a positive disconfirmation of expectation could have prompted participants in this study to be motivated to process more information about the SEMWOM, reflect on its usefulness and assess credibility in their evaluation of the airlines' reputations included in the study, versus the negative valence SEMWOM in which emotions played more of a role. Hence, through a positive disconfirmation of expectation the positive service encounters could have been in contrast to the expectations and reputation of the airlines in the microblog environment and resulted in these constructs being more predominant in the positive valence models. This finding therefore adds to the extant literature on cognitive information processing, message usefulness and the role of credibility of eWOM in the service encounter and microblog contexts.

\section{Managerial implications}

Be diligent and use social listening tools. First, managers must be diligent, as our findings suggest that a change in firm reputation does indeed occur when receivers are exposed 
to positive and negative valence SEMWOM. As such, managers should use social media management tools to diligently monitor service encounters about their firms. Doing so could provide opportunities to enhance their reputations when positive SEMWOM is shared and protect it when negative SEMWOM is shared.

Amplify positive SEMWOM and engage with it. Second, our study indicates that managers should try to amplify positive SEMWOM as firms' reputations can potentially be enhanced through the joy that receivers feel after being exposed to positive SEMWOM. Further, receivers of positive SEMWOM specifically are interested in processing issue-relevant information upon exposure, meaning that brand managers have an opportunity to engage with SEMWOM sharers and receivers to provide information that may be helpful in supporting the validity of the service encounter.

Pay attention to peripheral cues with negative SEMWOM. Our study demonstrates that receivers evaluate firms' reputations in some industries after exposure to negative SEMWOM based primarily on peripheral cues such as emotions. It is thus important that managers work to both minimize exposure to negative SEMWOM and to use defusing language in response to it.

Credibility is not always important. Finally, it is important for managers to understand that the credibility of negative SEMWOM can play a minimal role in predicting receivers' evaluation of a firm's reputation. In social media environments filled with misinformation and disinformation, it is thus important that managers act quickly to ensure that their voice is inserted as early as possible when negative SEMWOM is shared about their firms.

\section{Limitations and future research}

Limitations associated with this study may pave the way for future research. A key limitation is our focus on the airline industry. We chose this industry because it was at the epicenter of service encounter tweets and also offered a wealth of data. Although the use of this industry was a 
practical one for a sound execution of the study, research could undertake a similar study with another industry or even a range of industries to determine whether similar outcomes would occur. Another limitation is the location of the experiment (the United States). Given that microblog users can share their experiences of firms with anyone around the world, research should undertake a similar analysis with receivers in other countries. Finally, the study focused on one social media platform, Twitter. It would be worthwhile for research to undertake a similar study using other microblogging applications to determine whether our results hold. 


\section{References}

Abney, A.K., Pelletier, M.J., Ford, T.S. and Horky, A.B. (2017), “\# IHateYourBrand: adaptive service recovery strategies on Twitter", Journal of Services Marketing, Vol. 31 No. 3, pp. 281-294.

Abratt, R. and Kleyn, N. (2012), “Corporate identity, corporate branding and corporate reputations", European Journal of Marketing, Vol. 46 No. 7/8, pp. 1048-1063.

Allsop, D.T., Bassett, B.R. and Hoskins, J.A. (2007), "Word-of-mouth research: principles and applications", Journal of Advertising Research, Vol. 47 No. 4, pp. 398-411.

Argenti, P.A. and Druckenmiller, B. (2004), "Reputation and the corporate brand", Corporate Reputation Review, Vol. 6 No. 4, pp. 368-374.

Bain (2020), "The history of the Net Promoter Score ${ }^{\circledR}$ ", available at: http://www.netpromotersystem.com/about/why-net-promoter.aspx (accessed 26 June 2019).

Berger, J. and Milkman, K.L. (2012), “What makes online content viral?”, Journal of Marketing Research, Vol. 49 No. 2, pp. 192-205.

Berthon, P.R., Pitt, L.F., Plangger, K. and Shapiro, D. (2012), "Marketing meets Web 2.0, social media, and creative consumers: implications for international marketing strategy", Business Horizons, Vol. 55 No. 3, pp. 261-271.

Bitner, M.J. (1990), "Evaluating service encounters: the effects of physical surroundings and employee responses", Journal of Marketing, Vol. 54 No. 2, pp.69-82. 
Bowerman, M. and Aulbach, L. (2017), "United Airlines under fire after man is dragged off overbooked flight", available at: https://www.usatoday.com/story/travel/nationnow/2017/04/10/united-under-fire-after-man-dragged-off-overbooked-flight/100287740/ (accessed 26 June 2019).

Bowling, A. (2005), “Just one question: if one question works, why ask several?”, Journal of Epidemiology and Community Health, Vol. 59 No. 5, pp. 342-345.

Breazeale, M. (2009), "Word of mouse an assessment of electronic word-of-mouth research", International Journal of Market Research, Vol. 51 No. 3, pp. 297-318.

Cadotte, E.R., Woodruff, R.B. and Jenkins, R.L. (1987), "Expectations and norms in models of consumer satisfaction”, Journal of Marketing Research, Vol. 24 No. 3, pp. 305-314.

Cheng, V.T. and Loi, M.K. (2014), "Handling negative online customer reviews: the effects of elaboration likelihood model and distributive justice", Journal of Travel \& Tourism Marketing, Vol. 31 No, 1, pp. 1-15.

Cheung, C.M. and Thadani, D.R. (2012), “The impact of electronic word-of-mouth communication: a literature analysis and integrative model”, Decision Support Systems, Vol. 54 No. 1, pp. 461-470.

Cheung, M.Y., Luo, C., Sia, C.L. and Chen, H. (2009), “Credibility of electronic word-of-mouth: informational and normative determinants of on-line consumer recommendations", International Journal of Electronic Commerce, Vol. 13 No. 4, pp. 9-38. 
Chu, S. and Kamal, S. (2008), "The effect of perceived blogger credibility and argument quality on message elaboration and brand attitudes: an exploratory study", Journal of Interactive Advertising, Vol. 8 No. 2, pp. 26-37.

Daugherty, T. and Hoffman, E. (2014), "eWOM and the importance of capturing consumer attention within social media", Journal of Marketing Communications, Vol. 20 No. 1/2, pp. $82-102$.

De Maeyer, P. (2012), "Impact of online consumer reviews on sales and price strategies: a review and directions for future research", Journal of Product \& Brand Management, Vol. 21 No. 2, pp. 132-139.

Fearnow, B. (2018), "Passengers outraged as Southwest Airlines kicks family off flight over todler tantrum", available at: http://www.newsweek.com/southwest-airlines-toddler-fitvideo-chicago-midway-atlanta-flight-1683-flight-847044 (accessed 28 June 2019).

Field, A. and Hole, G. (2002), How to Design and Report Experiments, Sage Publications, London.

Fournier, S. and Avery, J. (2011), “The uninvited brand”, Business Horizons, Vol. 54 No. 3, pp. 193-207.

Gehlbach, H. and Barge, S. (2012), "Anchoring and adjusting in questionnaire responses", Basic and Applied Social Psychology, Vol. 34 No. 5, pp. 417-433.

Gotsi, M. and Wilson, A.M. (2001), "Corporate reputation: seeking a definition”, Corporate Communications: An International Journal, Vol. 6 No. 1, pp. 24-30. 
Grégoire, Y., Salle, A. and Tripp, T.M. (2015), "Managing social media crises with your customers: the good, the bad, and the ugly", Business Horizons, Vol. 58 No. 2, pp. 173-182.

Greyser, S.A. (1999), “Advancing and enhancing corporate reputation”, Corporate Communications: An International Journal, Vol. 4 No. 4, pp. 177-181.

Griffith, E. (2018), “Consumer recommended 2018: the tech brands you love most”, available at: https://www.pcmag.com/news/365392/consumer-recommended-2018-the-tech-brands-youlove-most (accessed 20 June 2019).

Grisaffe, D.B. (2007), “Questions about the ultimate question: conceptual considerations in evaluating Reichheld's net promoter score (NPS)", Journal of Consumer Satisfaction, Dissatisfaction and Complaining Behavior, Vol. 20, pp. 36-53.

Hair, J.F., Hult, G.T.M., Ringle, C. and Sarstedt, M. (2016), A Primer on Partial Least Squares Structural Equation Modeling (PLS-SEM), Sage Publications, London.

Hasford, J., Hardesty, D.M. and Kidwell, B. (2015), "More than a feeling: emotional contagion effects in persuasive communication", Journal of Marketing Research, Vol. 52 No. 6, pp. $836-847$.

Hatfield, E., Cacioppo, J.T. and Rapson, R.L. (1993), “Emotional contagion”, Current Directions in Psychological Science, Vol. 2 No. 3, pp. 96-100.

Henkel, A.P., Boegershausen, J., Rafaeli, A. and Lemmink, J. (2017), “The social dimension of service interactions: observer reactions to customer incivility", Journal of Service Research, Vol. 20 No. 2, pp. 120-134. 
Hennig-Thurau, T., Wiertz, C. and Feldhaus, F. (2015), “Does Twitter matter? the impact of microblogging word of mouth on consumers' adoption of new movies", Journal of the Academy of Marketing Science, Vol. 43 No. 3, pp. 375-394.

Hyken, S. (2018), “The best and worst companies to do business with", available at: https://www.forbes.com/sites/shephyken/2018/07/12/the-best-and-worst-companies-to-dobusiness-with/\#5cef04d03a48 (accessed 28 June 2019).

Jansen, B.J., Zhang, M., Sobel, K. and Chowdury, A. (2009), “Twitter power: tweets as electronic word of mouth", Journal of the American Society for Information Science and Technology, Vol. 60 No. 11, pp. 2169-2188.

Kaplan, A.M. and Haenlein, M. (2010), "Users of the world, unite! The challenges and opportunities of social media”, Business Horizons, Vol. 53 No. 1, pp. 59-68.

Keiningham, T.L. Cooil, B., Andreassen, T.W. and Aksoy, L. (2007), “A longitudinal examination of net promoter and firm revenue growth", Journal of Marketing, Vol. 71 No. 3, pp. 39-51.

Kim, J. and Gupta, P. (2012), "Emotional expressions in online user reviews: how they influence consumers' product evaluations”, Journal of Business Research, Vol. 65 No. 7, pp. 985-992.

Kolowich, L. (2014), "Delighting people in 140 characters: an inside look at jet blue's customer service success", available at: https://blog.hubspot.com/marketing/jetblue-customer-servicetwitter\#sm.0001cwqfdky9kf05115v60e3zsu91 (accessed 28 March 2017). 
Kooser, A. (2018), "Starbucks pumpkin spice latte debut gives twitter the shivers", available at: https://www.cnet.com/news/starbucks-pumpkin-spice-latte-debut-gives-twitter-the-shivers/ (accessed 28 March 2017).

Kumar, V., Choi, J.B. and Greene, M. (2017), "Synergistic effects of social media and traditional marketing on brand sales: capturing the time-varying effects", Journal of the Academy of Marketing Science, Vol. 45 No. 2, pp. 268-288.

Laczniak, R.N. and Muehling, D.D. (1993), “The relationship between experimental manipulations and tests of theory in an advertising message involvement context", Journal of Advertising, Vol. 22 No. 3, pp. 59-74.

Lewis, R.C. and Booms, B.H. (1983), “The marketing aspects of service quality”, Emerging Perspectives on Services Marketing, Vol. 65 No. 4, pp. 99-107.

Lin, T.M., Lu, K. and Wu, J. (2012), “The effects of visual information in eWOM communication”, Journal of Research in Interactive Marketing, Vol. 6 No. 1, pp. 7-26.

Marchand, A., Hennig-Thurau, T. and Wiertz, C. (2017), "Not all digital word of mouth is created equal: understanding the respective impact of consumer reviews and microblogs on new product success", International Journal of Research in Marketing, Vol. 34 No. 2, pp. $336-354$.

Morales, A.C., Wu, E.C. and Fitzsimons, G.J. (2012), "How disgust enhances the effectiveness of fear appeals", Journal of Marketing Research, Vol. 49 No. 3, pp. 383-393. 
Morgan, B. (2018), "The top 5 industries most hated by customers", available at: https://www.forbes.com/sites/blakemorgan/2018/10/16/top-5-most-hated-industries-bycustomers/\#5510fd6a90b5 (accessed 28 June 2019).

Oliver, R.L. (1980), “A cognitive model of the antecedents and consequences of satisfaction decisions", Journal of Marketing Research, Vol. 17 No. 4, pp. 460-469.

Park, C., Wang, Y., Yao, Y. and Kang, Y.R. (2011), "Factors influencing eWOM effects: using experience, credibility, and susceptibility”, International Journal of Social Science and Humanity, Vol. 1 No. 1, 74-79

Pasternak, O., Veloutsou, C. and Morgan-Thomas, A. (2017), "Self-presentation, privacy and electronic word-of-mouth in social media", Journal of Product \& Brand Management, Vol. 26 No. 4, pp. 415-428.

Petty, R.E. and Cacioppo, J.T. (1980), “Effects of issue involvement on attitudes in an advertising context," in Proceedings of the Division 23 Program, eds. Gerald G. Gom and Marvin E. Goldberg, Montreal, Canada: American Psychological Association, 75-79.

Pew Research Center. (2018). "Social media fact sheet", available at: http://www.pewinternet.org/fact-sheet/social-media/ (accessed 28 April 2018).

Plutchik, R. (2001), “The nature of emotions human emotions have deep evolutionary roots, a fact that may explain their complexity and provide tools for clinical practice", American Scientist, Vol. 89 No. 4, pp. 344-350. 
Poiesz, T.B. (1989), “The image concept: its place in consumer psychology", Journal of Economic Psychology, Vol. 10 No. 4, pp. 457-472.

Rauschnabel, P.A., Kammerlander, N. and Ivens, B.S. (2016), “Collaborative brand attacks in social media: exploring the antecedents, characteristics, and consequences of a new form of brand crises”, Journal of Marketing Theory and Practice, Vol. 24 No. 4, pp. 381-410.

Richins, M.L. (1984), "Word of mouth communication as negative information”, in Kinnear, T.C. (Ed.), Advances in Consumer Research, Vol. 11, Association for Consumer Research, Provo, UT, pp. 697-702

Rumney, E. (2018), “Britain's TSB hit by another IT glitch, angering some customers”, available at: https://www.businessinsider.com/r-britains-tsb-hit-by-another-it-glitch-angering-somecustomers-2018-9?r=UK\&IR=T (accessed 28 April 2018).

Satmetrix. (2019), “What is net promoter?”, available at: https://www.netpromoter.com/know/ (accessed 26 June 2019).

Sengupta, A.S., Balaji, M.S. and Krishnan, B.C. (2015), "How customers cope with service failure? A study of brand reputation and customer satisfaction", Journal of Business Research, Vol. 68 No. 3, pp. 665-674.

Shimp, T.A. and Stuart, E.W. (2004), "The role of disgust as an emotional mediator of advertising effects", Journal of Advertising, Vol. 33 No. 1, pp. 43-53. 
Siano, A., Vollero, A. and Palazzo, M. (2011), “Exploring the role of online consumer empowerment in reputation building: research questions and hypotheses", Journal of Brand Management, Vol. 19 No. 1, pp. 57-71.

Skytrax. (2018), “About airline star rating”, available at: https://skytraxratings.com/about-airlinerating (accessed 15 March 2018).

Solomon, M.R., Surprenant, C., Czepiel, J.A. and Gutman, E.G. (1985), “A role theory perspective on dyadic interactions: the service encounter", Journal of Marketing, Vol. 49 No. 1, pp. 99-111.

Standing, C., Holzweber, M. and Mattsson, J. (2016), “Exploring emotional expressions in eword-of-mouth from online communities", Information Processing \& Management, Vol. 52 No. 5, pp. 721-732.

Stevens, J.L., Spaid, B.I., Breazeale, M. and Jones, C.L.E. (2018), “Timeliness, transparency, and trust: a framework for managing online customer complaints", Business Horizons, Vol. 61 No. 3, pp. 375-384.

Stieglitz, S. and Dang-Xuan, L. (2013), “Emotions and information diffusion in social mediasentiment of microblogs and sharing behavior", Journal of Management Information Systems, Vol. 29 No. 4, pp. 217-248.

Sweeney, J.C., Soutar, G.N. and Mazzarol, T. (2012), "Word of mouth: measuring the power of individual messages", European Journal of Marketing, Vol. 46 No. 1/2, pp. 237-257.

Tabachnick, B.G. and Fidell, L.S. (2013), Using Multivariate Statistics, Pearson, Boston, MA. 
Teng, S., Khong, K.W. and Goh, W.W. (2014a), “Conceptualizing persuasive messages using ELM in social media”, Journal of Internet Commerce, Vol. 13 No. 1, pp. 65-87.

Teng, S., Wei Khong, K., Wei Goh, W. and Yee Loong Chong, A. (2014b), “Examining the antecedents of persuasive eWOM messages in social media", Online Information Review, Vol. 38 No. 6, pp. 746-768.

Wang, S., Cunningham, N.R. and Eastin, M.S. (2015), “The impact of eWOM message characteristics on the perceived effectiveness of online consumer reviews", Journal of Interactive Advertising, Vol. 15 No. 2, pp. 151-159.

Walker, K. (2010), “A systematic review of the corporate reputation literature: definition, measurement, and theory", Corporate Reputation Review, Vol. 12 No. 4, pp. 357-387.

Wolfe, J. (2018), “Want faster airline customer service? Try tweeting”, available at: https://www.nytimes.com/2018/11/20/travel/airline-customer-service-twitter.html (accessed 21 December 2018).

Wong, K.K. (2013), "Partial least squares structural equation modeling (PLS-SEM) techniques using SmartPLS”, Marketing Bulletin, Vol. 24 No. 1, pp. 1-32.

Yusuf, A.S., Che Hussin, A.R. and Busalim, A.H. (2018), "Influence of e-WOM engagement on consumer purchase intention in social commerce", Journal of Services Marketing, Vol. 32 No. 4, pp. 493-504. 


\section{Appendix}

[INSERT TABLES A.1 - A.3 HERE]

[INSERT FIGURES A.1-A.4 HERE] 
Table I. Summary Statistics. Panel A of the table below shows summary statistics for NPS scores for both positive and negative SEMWOM delineated by type of tweet. Panel B shows pair-wise t-tests for each group.

\begin{tabular}{|l|l|r|r|r|r|}
\hline \multicolumn{2}{|l|}{ A. Summary Statistics } & & & & \\
\hline Positive & & \multicolumn{1}{l|}{ Mean } & \multicolumn{1}{l|}{ SD } & Correlation & p-value \\
\hline Video & Initial NPS & 5.118 & 2.321 & 0.584 & 0.000 \\
\hline & Final NPS & 5.941 & 1.909 & & \\
\hline Photo & Initial NPS & 4.581 & 1.980 & 0.353 & 0.000 \\
\hline & Final NPS & 5.847 & 1.820 & & \\
\hline Text & Initial NPS & 5.930 & 2.357 & 0.384 & 0.000 \\
\hline & Final NPS & 6.984 & 1.938 & & \\
\hline Negative & & Mean & SD & Correlation & p-value \\
\hline Video & Initial NPS & 4.806 & 2.088 & 0.389 & 0.000 \\
\hline & Final NPS & 3.387 & 2.138 & & \\
\hline Photo & Initial NPS & 5.301 & 2.424 & 0.581 & 0.000 \\
\hline & Final NPS & 3.731 & 2.182 & & \\
\hline Text & Initial NPS & 5.169 & 2.262 & 0.418 & 0.000 \\
\hline & Final NPS & 3.688 & 0.098 & & \\
\hline B. Differences & & & & \\
\hline Positive & Pairs T-Test & p-value & Negative & Pairs T-Test & p-value \\
\hline Video & 8.075 & 0.000 & Video & -11.719 & 0.000 \\
\hline Photo & 11.268 & 0.000 & Photo & -14.292 & 0.000 \\
\hline Text & 8.383 & 0.000 & Text & -12.621 & 0.000 \\
\hline
\end{tabular}


Table II. Positive PLS-SEM Results. Panel A of the table below shows PLS-SEM models for positive SEMWOM separated by type of tweet. Coefficients and t-statistics are found by bootstrapping 5,000 times. Panel B shows an OLS regression that contains only the initial NPS and an intercept.

\begin{tabular}{|c|c|c|c|c|c|c|c|c|c|c|c|c|c|}
\hline \multicolumn{14}{|c|}{ Panel A: PLS-SEM Model Results } \\
\hline & & \multicolumn{4}{|c|}{ Video } & \multicolumn{4}{|c|}{ Photo } & \multicolumn{4}{|c|}{ Text Only } \\
\hline & & Coefficient & T-Stat. & $\begin{array}{c}\text { P- } \\
\text { Value }\end{array}$ & $\begin{array}{l}\text { Significance/ } \\
\text { Hypothesis }\end{array}$ & Coefficient & T-Stat. & P-Value & $\begin{array}{l}\text { Significance/ } \\
\text { Hypothesis }\end{array}$ & $\begin{array}{c}\text { Coefficie } \\
\text { nt }\end{array}$ & T-Stat. & P-Value & $\begin{array}{c}\text { Significance/ } \\
\text { Hypothesis }\end{array}$ \\
\hline NPS1 & & 0.317 & 6.775 & 0.000 & Significant & 0.285 & 6.297 & 0.000 & Significant & 0.406 & 9.731 & 0.000 & Significant \\
\hline \multicolumn{14}{|c|}{ SEMWOM Constructs: } \\
\hline $\begin{array}{l}\text { Message } \\
\text { Usefulness }\end{array}$ & $\mathrm{H} 3$ & 0.168 & 2.306 & 0.021 & Supported & 0.281 & 4.277 & 0.000 & Supported & 0.054 & 1.073 & 0.283 & Not supported \\
\hline $\begin{array}{l}\text { Message } \\
\text { Cred. }\end{array}$ & $\mathrm{H} 4$ & 0.083 & 1.764 & 0.078 & Not supported & 0.187 & 3.468 & 0.001 & Supported & 0.232 & 3.403 & 0.000 & Supported \\
\hline Issue Inv. & H6 & 0.189 & 3.007 & 0.003 & Supported & 0.112 & 2.077 & 0.038 & Supported & 0.205 & 4.744 & 0.000 & Supported \\
\hline \multicolumn{14}{|c|}{ SEMWOM Emotions: } \\
\hline Anger & H5 & 0.056 & 0.668 & 0.504 & Not supported & 0.122 & 1.415 & 0.157 & Not supported & 0.023 & 0.269 & 0.788 & Not supported \\
\hline Approval & H5 & 0.112 & 1.958 & 0.05 & Supported & 0.064 & 1.289 & 0.198 & Not supported & -0.024 & 0.709 & 0.478 & Not supported \\
\hline Disgust & H5 & -0.112 & 1.041 & 0.298 & Not supported & -0.239 & 1.934 & 0.053 & Not supported & -0.094 & 1.169 & 0.242 & Not supported \\
\hline Fear & H5 & 0.077 & 0.724 & 0.469 & Not supported & -0.047 & 0.532 & 0.595 & Not supported & 0.078 & 0.785 & 0.433 & Not supported \\
\hline Joy & $\mathrm{H} 5$ & 0.171 & 2.524 & 0.012 & Supported & 0.141 & 2.364 & 0.018 & Supported & 0.197 & 3.842 & 0 & Supported \\
\hline $\begin{array}{l}\text { Not } \\
\text { Surprised } \\
\end{array}$ & H5 & -0.038 & 0.857 & 0.392 & Not supported & 0.012 & 0.475 & 0.634 & Not supported & -0.04 & 1.271 & 0.204 & Not supported \\
\hline Sadness & H5 & -0.133 & 1.486 & 0.137 & Not supported & 0.01 & 0.217 & 0.828 & Not supported & -0.039 & 0.875 & 0.381 & Not supported \\
\hline Surprise & H5 & -0.04 & 1.245 & 0.213 & Not supported & 0.011 & 0.394 & 0.694 & Not supported & -0.066 & 1.753 & 0.08 & Not supported \\
\hline \multicolumn{14}{|c|}{ Demographics: } \\
\hline Age & & -0.052 & 1.536 & 0.125 & Not significant & -0.136 & 3.003 & 0.003 & Significant & -0.045 & 1.227 & 0.22 & Not significant \\
\hline Daily Use & & -0.006 & 0.273 & 0.785 & Not significant & 0.023 & 0.941 & 0.347 & Not significant & 0.011 & 0.551 & 0.581 & Not significant \\
\hline Education & & 0.025 & 0.932 & 0.351 & Not significant & 0.086 & 2.176 & 0.03 & Significant & 0.026 & 0.939 & 0.348 & Not significant \\
\hline Sex & & 0.023 & 0.913 & 0.361 & Not significant & 0.043 & 1.447 & 0.148 & Not significant & 0.039 & 1.387 & 0.165 & Not significant \\
\hline $\mathbf{R}^{2}=$ & & 0.52 & & & & 0.574 & & & & 0.593 & & & \\
\hline \multicolumn{14}{|c|}{ Panel B: OLS of the final NPS using only the original NPS } \\
\hline & & \multicolumn{4}{|c|}{ Video } & \multicolumn{4}{|c|}{ Photo } & \multicolumn{3}{|c|}{ Text } & \\
\hline & & Coefficient & T-Stat. & $\begin{array}{c}\text { P- } \\
\text { Value }\end{array}$ & & Coefficient & T-Stat. & P-Value & & $\begin{array}{c}\text { Coefficie } \\
\text { nt }\end{array}$ & T-Stat. & P-Value & \\
\hline
\end{tabular}




\begin{tabular}{|l|l|l|l|l|l|l|l|l|l|l|c|c|c|}
\hline & NPS1 & 0.314 & 7.992 & 1.706 & Not significant & 0.323 & 7.252 & 2.428 & Not significant & 0.478 & 13.838 & 2.181 & Not significant \\
2 \\
\cline { 2 - 15 } \\
4
\end{tabular}$$
6
$$$$
7
$$$$
8
$$$$
9
$$$$
10
$$$$
11
$$

12

13

14

15

16

17

18

19

20

21

22

23

24

25

26

4

44

45 
Table III. Negative PLS SEM Models. Panel A of the table below shows PLS-SEM models for negative SEMWOM separated by type of tweet. Coefficients and t-statistics are found by bootstrapping 5,000 times. Panel B shows an OLS regression that contains only the initial NPS and an intercept.

\begin{tabular}{|c|c|c|c|c|c|c|c|c|c|c|c|c|c|}
\hline \multicolumn{14}{|c|}{ Panel A: PLS-SEM Model Results } \\
\hline & & \multicolumn{4}{|c|}{ Video } & \multicolumn{4}{|c|}{ Photo } & \multicolumn{4}{|c|}{ Text Only } \\
\hline & & Coefficient & T-Stat. & P-Value & $\begin{array}{l}\text { Significance/ } \\
\text { Hypothesis }\end{array}$ & Coefficient & T-Stat. & P-Value & $\begin{array}{c}\text { Significance/ } \\
\text { Hypothesis }\end{array}$ & Coefficient & T-Stat. & $\begin{array}{c}\text { P- } \\
\text { Value }\end{array}$ & $\begin{array}{c}\text { Significance/ } \\
\text { Hypothesis }\end{array}$ \\
\hline NPS1 & & 0.377 & 7.604 & 0.000 & Significant & 0.52 & 11.892 & 0.000 & Significant & 0.471 & 8.692 & 0.000 & Significant \\
\hline \multicolumn{14}{|c|}{ SEMWOM Constructs: } \\
\hline $\begin{array}{l}\text { Message } \\
\text { Usefulness }\end{array}$ & H3 & -0.175 & 2.357 & 0.018 & Supported & -0.065 & 1.318 & 0.188 & Not supported & -0.127 & 1.859 & 0.063 & Not supported \\
\hline $\begin{array}{l}\text { Message } \\
\text { Cred. }\end{array}$ & $\mathrm{H} 4$ & 0.009 & 0.235 & 0.814 & Not supported & -0.103 & 2.193 & 0.028 & Supported & -0.121 & 1.92 & 0.055 & Not supported \\
\hline Issue Inv. & H6 & -0.108 & 1.953 & 0.051 & Not supported & -0.147 & 3.009 & 0.003 & Supported & 0.004 & 0.119 & 0.906 & Not supported \\
\hline \multicolumn{14}{|c|}{ SEMWOM Emotions: } \\
\hline Anger & $\mathrm{H} 5$ & -0.15 & 2.354 & 0.019 & Supported & -0.055 & 1.187 & 0.235 & Not supported & -0.11 & 1.591 & 0.112 & Not supported \\
\hline Approval & H5 & 0.103 & 2.039 & 0.042 & Supported & 0.152 & 2.856 & 0.004 & Supported & 0.091 & 1.43 & 0.153 & Not supported \\
\hline Disgust & H5 & -0.192 & 3.027 & 0.002 & Supported & -0.142 & 2.531 & 0.011 & Supported & -0.113 & 1.787 & 0.074 & Not supported \\
\hline Fear & H5 & 0.1 & 1.954 & 0.051 & Not supported & -0.107 & 1.857 & 0.063 & Not supported & -0.07 & 1.069 & 0.285 & Not supported \\
\hline Joy & $\mathrm{H} 5$ & 0.095 & 1.9 & 0.058 & Not supported & 0.022 & 0.658 & 0.511 & Not supported & 0.187 & 2.639 & 0.008 & Supported \\
\hline $\begin{array}{l}\text { Not } \\
\text { Surprised }\end{array}$ & $\mathrm{H} 5$ & -0.027 & 0.778 & 0.437 & Not supported & 0 & 0.011 & 0.991 & Not supported & -0.116 & 2.218 & 0.027 & Supported \\
\hline Sadness & H5 & -0.098 & 1.875 & 0.061 & Not supported & 0.045 & 1.165 & 0.244 & Not supported & -0.069 & 1.326 & 0.185 & Not supported \\
\hline Surprise & H5 & -0.04 & 1.013 & 0.311 & Not supported & -0.019 & 0.545 & 0.586 & Not supported & -0.042 & 0.938 & 0.348 & Not supported \\
\hline \multicolumn{14}{|c|}{ Demographics: } \\
\hline Age & & -0.01 & 0.365 & 0.715 & Not significant & 0.058 & 1.529 & 0.126 & Not significant & 0.041 & 1.046 & 0.295 & Not significant \\
\hline Daily Use & & 0.011 & 0.431 & 0.667 & Not significant & -0.023 & 0.875 & 0.382 & Not significant & -0.018 & 0.644 & 0.519 & Not significant \\
\hline Education & & 0.075 & 1.82 & 0.069 & Not significant & 0.019 & 0.644 & 0.519 & Not significant & 0.055 & 1.251 & 0.211 & Not significant \\
\hline Sex & & -0.057 & 1.629 & 0.103 & Not significant & -0.033 & 1.114 & 0.265 & Not significant & 0.02 & 0.695 & 0.487 & Not significant \\
\hline $\mathbf{R}^{2}=$ & & 0.447 & & & & 0.485 & & & & 0.366 & & & \\
\hline \multicolumn{14}{|c|}{ Panel B: OLS of the final NPS using only the original NPS } \\
\hline & & \multicolumn{4}{|c|}{ Video } & \multicolumn{4}{|c|}{ Photo } & \multicolumn{3}{|c|}{ Text Only } & \\
\hline & & Coefficient & T-Stat. & P-Value & & Coefficient & T-Stat. & P-Value & & Coefficient & T-Stat. & $\begin{array}{c}\text { P- } \\
\text { Value }\end{array}$ & \\
\hline
\end{tabular}




\begin{tabular}{|c|c|c|c|c|c|c|c|c|c|c|c|c|c|}
\hline 1 & NPS1 & 0.399 & 8.128 & 2.105 & Not significant & 0.523 & 13.744 & 5.169 & Not significant & 0.351 & 8.859 & 3.432 & Not significant \\
\hline 2 & Intercept & 1.472 & 5.728 & 6.608 & Not significant & 0.957 & 4.311 & 2.087 & Not significant & 1.876 & 8.399 & 9.716 & Not significant \\
\hline 4 & $\mathbf{r}^{2}=$ & 0.152 & & & & $\mathbf{0 . 3 3 7}$ & & & & 0.175 & & & \\
\hline
\end{tabular}

6

7

9

10

11

12

13

14

15

16

17

18

19

20

21

22

23

24

25

26

27

28

29

30

31

32

33

34

35

36

37

38

39

40

41

42

43

44

46 
Table A.1 - Constructs and Scale Items. Table A.1 demonstrates the single and multi-item constructs, the routes to persuasion, the scale items used and the supporting references.

\begin{tabular}{|c|c|c|c|}
\hline Construct Measured & Route to Persuasion & Scale Items & Major References \\
\hline $\begin{array}{l}\text { SEMWOM Message } \\
\text { Credibility }\end{array}$ & $\begin{array}{l}\text { Peripheral (Petty \& } \\
\text { Cacioppo, 1980) }\end{array}$ & $\begin{array}{l}\text { Thinking about this Tweet, to what } \\
\text { extent do you agree or disagree with } \\
\text { the following statements? } \\
\text { - The tweet is believable. } \\
\text { - The tweet is informative. } \\
\text { - The tweet is trustworthy. }\end{array}$ & $\begin{array}{l}\text { Park, Wang, Yao, \& Kang, } \\
\text { 2011; Cheung et al., } 2009\end{array}$ \\
\hline $\begin{array}{l}\text { SEMWOM Message } \\
\text { Usefulness }\end{array}$ & $\begin{array}{l}\text { Peripheral (Richens, } \\
\text { 1984; Petty \& } \\
\text { Cacioppo, 1980) }\end{array}$ & $\begin{array}{l}\text { Thinking about this tweet, to what } \\
\text { extent do you agree or disagree with } \\
\text { the following statements? } \\
\text { - The tweet is useful. } \\
\text { - The tweet is interesting. } \\
\text { - The tweet is worth } \\
\text { - I liked the tweet. }\end{array}$ & Laczniak \& Muehling, 1993 \\
\hline $\begin{array}{l}\text { SEMWOM Issue } \\
\text { Involvement }\end{array}$ & $\begin{array}{l}\text { Central (Richens, } \\
\text { 1984; Petty \& } \\
\text { Cacioppo, 1980) }\end{array}$ & $\begin{array}{l}\text { After seeing this tweet, how likely are } \\
\text { you to do the following? } \\
\text { - Expand it to read (airline) } \\
\text { response }\end{array}$ & Petty, \& Cacioppo, 1980 \\
\hline
\end{tabular}




\begin{tabular}{|c|c|c|c|}
\hline & & $\begin{array}{l}\text { - Expand to read comments of } \\
\text { others } \\
\text { - Click to favorite it } \\
\text { - Click to retweet it }\end{array}$ & \\
\hline SEMWOM Emotions & $\begin{array}{l}\text { Peripheral (Petty \& } \\
\text { Cacioppo, 1980) }\end{array}$ & $\begin{array}{l}\text { Reflecting on this tweet, to what } \\
\text { extent do you feel the following } \\
\text { emotions? } \\
\text { - Joy } \\
\text { - Sadness } \\
\text { - Surprise } \\
\text { - Not surprised } \\
\text { - Anger } \\
\text { - Fear } \\
\text { - Disgust } \\
\text { - Approval }\end{array}$ & Plutchik, 2001 \\
\hline
\end{tabular}

30

31

32

33

3

35

37

39

41

43

45 
Table A.2 - Positive Model Validity Results. Convergent validity was established as the average variance explained (AVE) by the multiple indicators of each latent variable was $>$ than 0.5 . Internal consistency reliability was established, as all of the composite reliability coefficients for the latent variables were $>0.6$ ( single-item constructs measure at 1$)$.

\begin{tabular}{|c|c|c|c|c|c|c|c|c|c|c|c|c|c|c|}
\hline Positive & & & & & & & & & & & & & & \\
\hline \multirow[t]{2}{*}{ Photo } & & & & & Text & & & & & Video & & & & \\
\hline & $\begin{array}{c}\text { Cronbach's } \\
\text { Alpha }\end{array}$ & rho_A & $\begin{array}{l}\text { Composite } \\
\text { Reliability }\end{array}$ & A.V.E. & & $\begin{array}{c}\text { Cronbach's } \\
\text { Alpha }\end{array}$ & rho_A & $\begin{array}{l}\text { Composite } \\
\text { Reliability }\end{array}$ & A.V.E. & & $\begin{array}{c}\text { Cronbach's } \\
\text { Alpha }\end{array}$ & rho_A & $\begin{array}{l}\text { Composite } \\
\text { Reliability }\end{array}$ & A.V.E. \\
\hline Initial NPS & 1 & 1 & 1 & 1 & Initial NPS & 1 & 1 & 1 & 1 & Initial NPS & 1 & 1 & 1 & 1 \\
\hline Final NPS & 1 & 1 & 1 & 1 & Final NPS & 1 & 1 & 1 & 1 & Final NPS & 1 & 1 & 1 & 1 \\
\hline \multicolumn{15}{|l|}{$\begin{array}{l}\text { SEMWOM } \\
\text { Constructs: }\end{array}$} \\
\hline $\begin{array}{l}\text { Issue } \\
\text { Involvement }\end{array}$ & 0.854 & 0.855 & 0.901 & 0.695 & $\begin{array}{l}\text { Issue } \\
\text { Involvement }\end{array}$ & 0.795 & 0.803 & 0.866 & 0.619 & $\begin{array}{l}\text { Issue } \\
\text { Involvement }\end{array}$ & 0.893 & 0.894 & 0.926 & 0.757 \\
\hline $\begin{array}{l}\text { Message } \\
\text { Credibility }\end{array}$ & 0.86 & 0.869 & 0.906 & 0.708 & $\begin{array}{l}\text { Message } \\
\text { Credibility }\end{array}$ & 0.827 & 0.838 & 0.885 & 0.658 & $\begin{array}{l}\text { Message } \\
\text { Credibility }\end{array}$ & 0.867 & 0.866 & 0.911 & 0.721 \\
\hline $\begin{array}{l}\text { Message } \\
\text { Usefulness }\end{array}$ & 0.915 & 0.917 & 0.94 & 0.798 & $\begin{array}{l}\text { Message } \\
\text { Usefulness }\end{array}$ & 0.852 & 0.863 & 0.9 & 0.692 & $\begin{array}{l}\text { Message } \\
\text { Usefulness }\end{array}$ & 0.895 & 0.896 & 0.927 & 0.762 \\
\hline \multicolumn{15}{|l|}{ Emotions: } \\
\hline Anger & 1 & 1 & 1 & 1 & Anger & 1 & 1 & 1 & 1 & Anger & 1 & 1 & 1 & 1 \\
\hline Approval & 1 & 1 & 1 & 1 & Approval & 1 & 1 & 1 & 1 & Approval & 1 & 1 & 1 & 1 \\
\hline Disgust & 1 & 1 & 1 & 1 & Disgust & 1 & 1 & 1 & 1 & Disgust & 1 & 1 & 1 & 1 \\
\hline Fear & 1 & 1 & 1 & 1 & Fear & 1 & 1 & 1 & 1 & Fear & 1 & 1 & 1 & 1 \\
\hline Joy & 1 & 1 & 1 & 1 & Joy & 1 & 1 & 1 & 1 & Joy & 1 & 1 & 1 & 1 \\
\hline Not Surprised & 1 & 1 & 1 & 1 & $\begin{array}{l}\text { Not } \\
\text { Surprised }\end{array}$ & 1 & 1 & 1 & 1 & $\begin{array}{l}\text { Not } \\
\text { Surprised }\end{array}$ & 1 & 1 & 1 & 1 \\
\hline Sadness & 1 & 1 & 1 & 1 & Sadness & 1 & 1 & 1 & 1 & Sadness & 1 & 1 & 1 & 1 \\
\hline Surprise & 1 & 1 & 1 & 1 & Surprise & 1 & 1 & 1 & 1 & Surprise & 1 & 1 & 1 & 1 \\
\hline \multicolumn{15}{|l|}{ Demographics: } \\
\hline Age & 1 & 1 & 1 & 1 & Age & 1 & 1 & 1 & 1 & Age & 1 & 1 & 1 & 1 \\
\hline Daily Use & 1 & 1 & 1 & 1 & Daily Use & 1 & 1 & 1 & 1 & Daily Use & 1 & 1 & 1 & 1 \\
\hline Education & 1 & 1 & 1 & 1 & Education & 1 & 1 & 1 & 1 & Education & 1 & 1 & 1 & 1 \\
\hline Sex & 1 & 1 & 1 & 1 & Sex & 1 & 1 & 1 & 1 & Sex & 1 & 1 & 1 & 1 \\
\hline
\end{tabular}


Table A.3 - Negative Model Validity Results. Convergent validity was established as the average variance explained (AVE) by the multiple indicators of each latent variable was $>$ than 0.5 . Internal consistency reliability was established, as all of the composite reliability coefficients for the latent variables were $>0.6$ (single-item constructs measure at 1$)$.

\begin{tabular}{|c|c|c|c|c|c|c|c|c|c|c|c|c|c|c|}
\hline \multicolumn{15}{|l|}{ Negative } \\
\hline Photo & & & & & Text & & & & & Video & & & & \\
\hline & $\begin{array}{c}\text { Cronbach's } \\
\text { Alpha }\end{array}$ & rho A & $\begin{array}{l}\text { Composite } \\
\text { Reliability }\end{array}$ & AVE & & $\begin{array}{c}\text { Cronbach's } \\
\text { Alpha }\end{array}$ & rho A & $\begin{array}{l}\text { Composite } \\
\text { Reliability }\end{array}$ & AVE & & $\begin{array}{c}\text { Cronbach's } \\
\text { Alpha }\end{array}$ & rho_A & $\begin{array}{l}\text { Composite } \\
\text { Reliability }\end{array}$ & AVE \\
\hline Initial NPS & 1 & 1 & 1 & 1 & Initial NPS & 1 & 1 & 1 & 1 & Initial NPS & 1 & 1 & 1 & 1 \\
\hline Final NPS & 1 & 1 & 1 & 1 & Final NPS & 1 & 1 & 1 & 1 & Final NPS & 1 & 1 & 1 & 1 \\
\hline \multicolumn{15}{|l|}{$\begin{array}{l}\text { SEMWOM } \\
\text { Constructs: }\end{array}$} \\
\hline $\begin{array}{l}\text { Issue } \\
\text { Involvement }\end{array}$ & 0.698 & 0.743 & 0.81 & 0.523 & $\begin{array}{l}\text { Issue } \\
\text { Involvement }\end{array}$ & 0.796 & 0.825 & 0.865 & 0.619 & $\begin{array}{l}\text { Issue } \\
\text { Involvement }\end{array}$ & 0.78 & 0.839 & 0.854 & 0.597 \\
\hline $\begin{array}{l}\text { Message } \\
\text { Credibility }\end{array}$ & 0.796 & 0.816 & 0.867 & 0.622 & $\begin{array}{l}\text { Message } \\
\text { Credibility }\end{array}$ & 0.881 & 0.906 & 0.919 & 0.741 & $\begin{array}{l}\text { Message } \\
\text { Credibility }\end{array}$ & 0.895 & 0.905 & 0.927 & 0.762 \\
\hline $\begin{array}{l}\text { Message } \\
\text { Usefulness }\end{array}$ & 0.792 & 0.816 & 0.864 & 0.614 & $\begin{array}{l}\text { Message } \\
\text { Usefulness }\end{array}$ & 0.881 & 0.904 & 0.917 & 0.734 & $\begin{array}{l}\text { Message } \\
\text { Usefulness }\end{array}$ & 0.872 & 0.877 & 0.912 & 0.722 \\
\hline \multicolumn{15}{|l|}{ Emotions: } \\
\hline Anger & 1 & 1 & 1 & 1 & Anger & 1 & 1 & 1 & 1 & Anger & 1 & 1 & 1 & 1 \\
\hline Approval & 1 & 1 & 1 & 1 & Approval & 1 & 1 & 1 & 1 & Approval & 1 & 1 & 1 & 1 \\
\hline Disgust & 1 & 1 & 1 & 1 & Disgust & 1 & 1 & 1 & 1 & Disgust & 1 & 1 & 1 & 1 \\
\hline Fear & 1 & 1 & 1 & 1 & Fear & 1 & 1 & 1 & 1 & Fear & 1 & 1 & 1 & 1 \\
\hline Joy & 1 & 1 & 1 & 1 & Joy & 1 & 1 & 1 & 1 & Joy & 1 & 1 & 1 & 1 \\
\hline Not Surprised & 1 & 1 & 1 & 1 & Not Surprised & 1 & 1 & 1 & 1 & Not Surprised & 1 & 1 & 1 & 1 \\
\hline Sadness & 1 & 1 & 1 & 1 & Sadness & 1 & 1 & 1 & 1 & Sadness & 1 & 1 & 1 & 1 \\
\hline Surprise & 1 & 1 & 1 & 1 & Surprise & 1 & 1 & 1 & 1 & Surprise & 1 & 1 & 1 & 1 \\
\hline Age & 1 & 1 & 1 & 1 & Age & 1 & 1 & 1 & 1 & Age & 1 & 1 & 1 & 1 \\
\hline Daily Use & 1 & 1 & 1 & 1 & Daily Use & 1 & 1 & 1 & 1 & Daily Use & 1 & 1 & 1 & 1 \\
\hline Education & 1 & 1 & 1 & 1 & Education & 1 & 1 & 1 & 1 & Education & 1 & 1 & 1 & 1 \\
\hline Sex & 1 & 1 & 1 & 1 & Sex & 1 & 1 & 1 & 1 & Sex & 1 & 1 & 1 & 1 \\
\hline
\end{tabular}




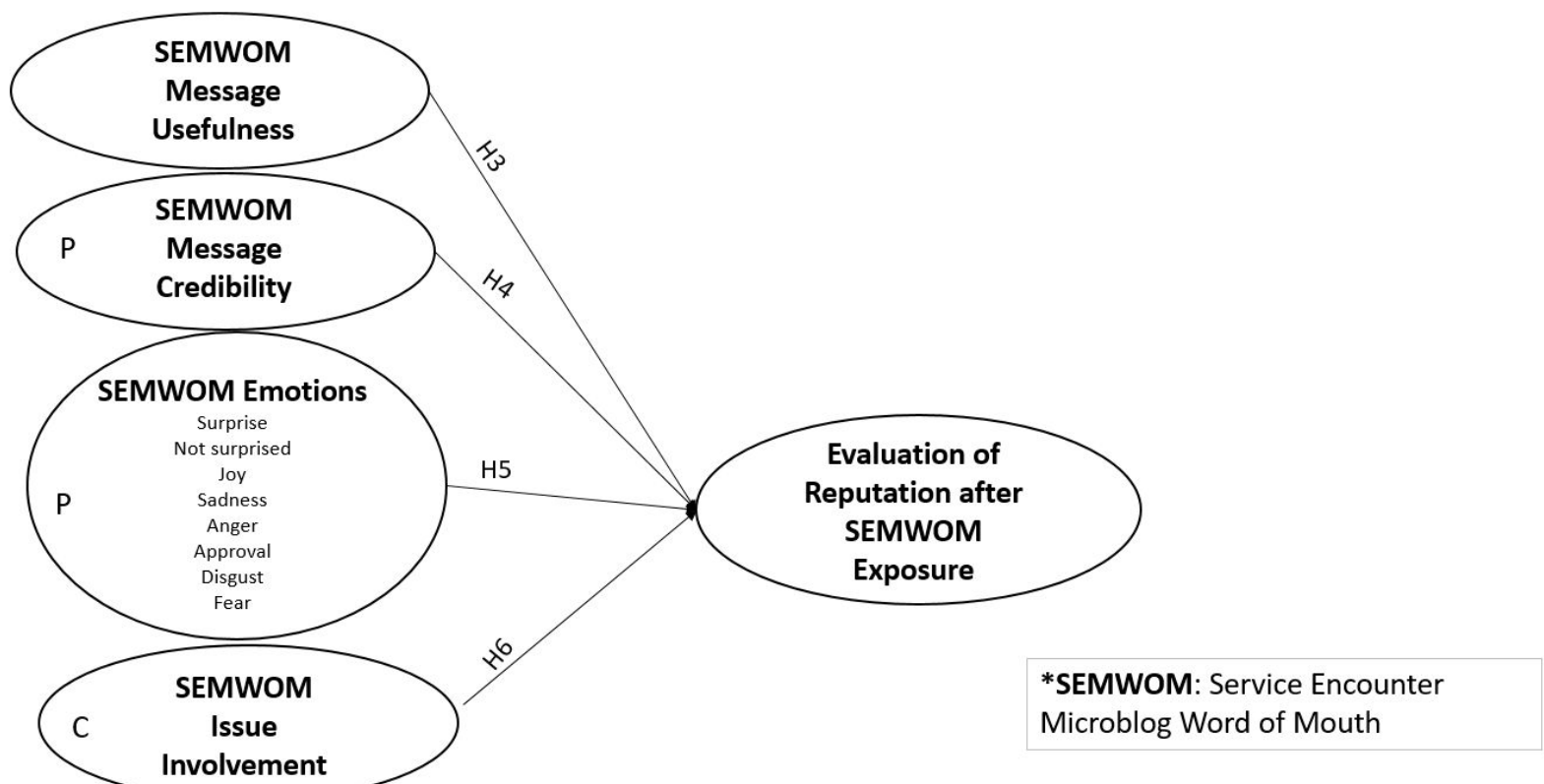

Figure 1 - SEMWOM Reputation Model
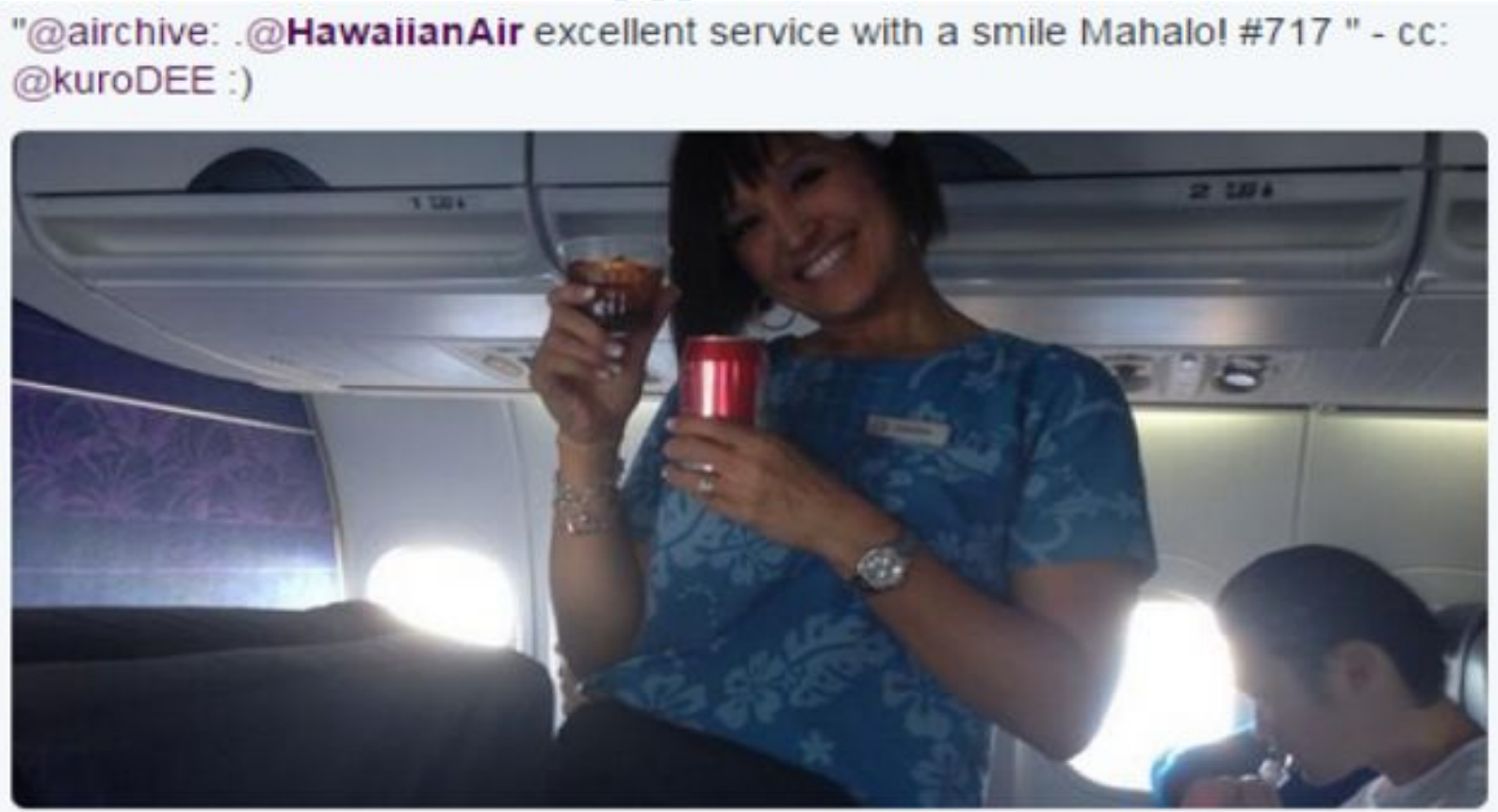

Figure A.1 - Positive SEMOM (photo) 


\section{@united 'KP You've restored my faith is customer service and the airlines. I really really really appreciate it. I'm crying. made my day. :)}

Figure A.2 - Positive SEMWOM (text only)

\section{@AmericanAir poor customer service exper., unfortunately. Agents weren't apologetic at all. :(I thought the airline had made some changes.}

Figure A.3 - Negative SEMWOM (text only)

Waiting over an hour and a half for my friend's luggage on @Delta for a flight delayed over 5 hours >:( @DeltaAssist

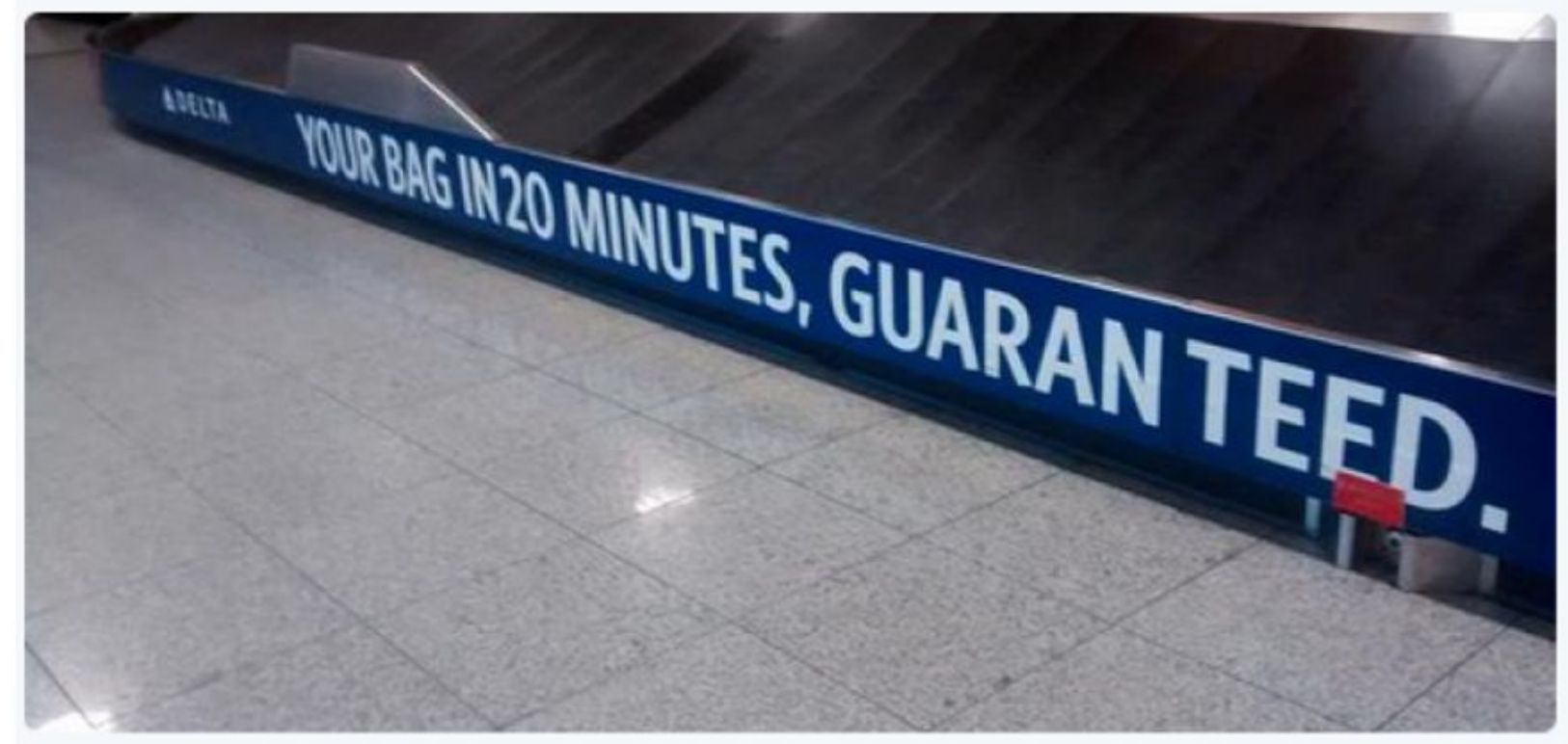

Figure A.4 - Negative SEMWOM (photo) 